\title{
Strategic Management, the Analysis and Audit of Development of Small Business in the Format of the Concept of the Resource Focused Approach
}

\author{
Liudmila Filobokova, Yurii Pesotsky, Olga Grigoreva \\ Department of Innovative Entrepreneurship, Bauman State Technical University, Moskov, Russia \\ Email address: \\ filobokova@list.ru (L. Filobokova),pessotski@yandex.ru(Y. Pesotsky),oporakadry@mail.ru(O. Grigoreva)
}

To cite this article:

Liudmila Filobokova, Yurii Pesotsky, Olga Grigoreva. Strategic Management, the Analysis and Audit of Development of Small Business in the Format of the Concept of the Resource Focused Approach. International Journal of Economic Behavior and Organization.

Vol. 7, No. 1, 2019, pp. 14-18. doi: 10.11648/j.ijebo.20190701.13

Received: February 18, 2019; Accepted: March 26, 2019; Published: April 18, 2019

\begin{abstract}
For the modern system of the world economy the vector of sustainable development is basic that finds reflection in strategic management of subsystems that form it - the national economy. Small business, which purpose of the development strategy for the medium term in the Russian Federation is increase in level of competitiveness and formation on this basis of the competitive environment in national economy of the country acts as the most capacious subsystem of national economy on quantitative characteristics. At the same time, one of the problems which are slowing down development of small business of the Russian Federation is its limited opportunities of resource providing. This circumstance imperatively predetermined development and justification of adequate approaches to strategic management, the analysis and audit of development of small business in a format of the concept of the resource focused approach.
\end{abstract}

Keywords: Small Business, Resource-Based Approach, Strategic Management, Analysis and Audit, Instrumental and Methodical Apparatus

\section{Introduction}

Small business solves a wide range of problems of economic, social and ecological character and, owing to the innovative character, is capable to form the competitive environment of national economy. At the same time, the certain difficulties connected, first of all, with limited resource providing that imperatively predetermines search of such approaches to its management, the analysis and audit which driver is resource-saving and ensuring effective business are characteristic of business in small organizational and economic forms of managing. One of economic concepts answering to such installations is the concept of the resource focused approach. The resource focused economy represents such economy which basic factor of growth is use of any resources [1].

The author believes that differences between economic growth and economic development are fundamental for an essence of the concept "stability" and "resource efficiency".
If growth is directed to quantitative increase in scales of economy in its physical measurement that assumes increase in volume and speed of the material and power flows passing through economy, proliferation of the population and increase in volume of stocks of products of human work, then development - high-quality improvements in structure, a design and composition of physical volumes and streams. Potential of the economic progress which is based on sustainable development assumes high-quality improvements more, than the economic growth based only on increase in quantitative indices. If the economic growth based only on quantitative indices eventually leads to selfdamage (and thus is "unstable"), then the economic development understood, first of all, in qualitative sense is steady. Such interpretation, according to the conclusion of authors, corresponds to logic of conceptual bases of the resource focused approach and is the basis for justifications of strategic management, the analysis and audit of development of small business. 


\section{Adaptation of the Concept of Resource-Based Approach to the Peculiarities of Strategic Management and Small Business}

Tasks of the strategy of development of small business of the Russian Federation is increase in level of competitiveness and formation on this basis of the competitive environment of national economy, considered as basic conditions of ensuring worthy level and quality of life of the population of the country [2]. The purposes and tasks declared the strategy of social and economic development of the Russian Federation until 2030 defined purposes and problems of development of systems of subordinate level, one of which is small business [3].

A. E. Karlik and V. V. Platonov, researching in the field of comparative assessment position and resource focused approaches to management, offered the following logical comparison (table 1).

Table 1. Logic of development of strategy according to position and resource focused by approaches.

\begin{tabular}{|c|c|}
\hline Position approach & Resource focused approach \\
\hline The analysis of that is wanted by the client & Analysis of resources and abilities of business \\
\hline Competitor analysis & The analysis of key competences and how they correspond to the external environment \\
\hline $\begin{array}{l}\text { Reduction of the internal environment of the organization in } \\
\text { compliance with the environment }\end{array}$ & Finding of the external environment, relevant firm \\
\hline $\begin{array}{l}\text { Strategy of creation/acquisition/development of resources and } \\
\text { organizational abilities for satisfaction of customer needs }\end{array}$ & $\begin{array}{l}\text { The strategy of creation/acquisition/development of channels for customer acquisition } \\
\text { which requirements the organization can satisfy (up to formation of such requirements) }\end{array}$ \\
\hline
\end{tabular}

The resource focused approach assumes new approach to model of development of strategy which feature is the fact that it is necessary to realize (to define) existence unique at each economic entity and proceeding from it to decide on production (and sale) certain goods to a certain market.

Based on an informative entity of model of the resource focused approach, the reason for the developing (developed) situation (both favorable, and negative) it is necessary to look for in small enterprise or activity of the individual entrepreneur, but not in their actions or a competitive situation.

In modern conditions the innovative nature of development providing improving competitiveness and resource-saving due to mainly intensive nature of progress of a system is of particular importance. In economic science two types of economic growth - extensive and intensive are considered, but at the same time it should be noted that in pure form there is neither extensive, nor intensive economic growth, and mainly one or other type [4].

The competitiveness of small business is provided with a number of factors signs and formed under the influence of intensive and extensive factors of growth and development, but the innovation acts as a basic factor (table 2).

Table 2. Intensive and extensive approaches to strategic management of the innovative capacity of small business entities.

\begin{tabular}{|c|c|c|}
\hline $\begin{array}{l}\text { The components forming } \\
\text { innovative potential }\end{array}$ & $\begin{array}{l}\text { The directions of growth and development within } \\
\text { extensive approach }\end{array}$ & $\begin{array}{l}\text { The directions of growth and development within intensive } \\
\text { approach }\end{array}$ \\
\hline Human resources & $\begin{array}{l}\text { Increase in number of staff, occupied with research } \\
\text { and development, including the personnel having } \\
\text { academic degrees. }\end{array}$ & $\begin{array}{l}\text { Increase in a qualitative component on the basis of knowledge and } \\
\text { competences providing the high level of innovation of projects and } \\
\text { administrative innovations. }\end{array}$ \\
\hline Natural resources & $\begin{array}{l}\text { Drawing into economic circulation of considerable } \\
\text { volumes and types of natural and other resources. }\end{array}$ & $\begin{array}{l}\text { Resource-saving by means of growth of a resource productivity } \\
\text { and decrease in resource intensity on the basis of innovations, use } \\
\text { of alternative resources, ensuring environmental safety and } \\
\text { reproduction of a biota to its inexhaustible capacity. }\end{array}$ \\
\hline Scientific resources & $\begin{array}{l}\text { Increase in specific weight of the educational sector } \\
\text { and sector occupied with research and development. }\end{array}$ & $\begin{array}{l}\text { Commercialization of the innovation products with the high level } \\
\text { of social and economic and environmental efficiency. } \\
\text { Generation of the business ideas at the level of enterprise } \\
\text { structures. Involvement of small business entities to basic and } \\
\text { application studies. }\end{array}$ \\
\hline $\begin{array}{l}\text { Resources of the } \\
\text { institutional environment }\end{array}$ & $\begin{array}{l}\text { Accumulation of quantity of regulatives (rules, } \\
\text { norms) regulating internal innovative activity of small } \\
\text { enterprises and individual entrepreneurs. }\end{array}$ & $\begin{array}{l}\text { Optimization and high-quality filling of a system of the standard } \\
\text { regulation eliminating discrepancies and contradictions. }\end{array}$ \\
\hline Information resources & $\begin{array}{l}\text { Growth of number of units of information connected } \\
\text { with innovative activity. }\end{array}$ & $\begin{array}{l}\text { Improvement of quality of the information massif (objectivity } \\
\text { completeness, accuracy, timeliness, relevance, etc.) }\end{array}$ \\
\hline
\end{tabular}




\section{Methodological Approaches to Strategic Analysis in Small Business Management Based on the Concept of Resource-Based Approach}

The economic analysis acting as function, tools of management traditionally investigates (its object are) the means of labor, objects of the labor, human and financial resources advanced in business activity and also financial results and a financial condition of a system. At the same time a purpose of its performance is qualitative and quantitative assessment of cause and effect interrelations for research of the "strongest" or "weak" positions (places) which need to be strengthened or abolished. The systemacity and complexity of methodology and technique of the economic analysis predetermine studying of use of resources in the "consumed resources" format - "result of consumption" [5]. In the strategic analysis the set of the indicators differing on hierarchical levels of systems where to each subject there correspond the set of indicators is used and each of indicators can accept various numerical values depending on efficiency of use of a resource of a concrete type that allows to set strategic reference points and to operate for the benefit of their achievement (table 3 ).

Table 3. The system of the indicators offered to use in the strategic analysis and management of small business entities on the basis of the resource focused approach.

\begin{tabular}{|c|c|c|c|}
\hline $\begin{array}{l}\text { Type of a } \\
\text { resource }\end{array}$ & Use indicator & $\begin{array}{l}\text { Calculation } \\
\text { algorithm }\end{array}$ & Semantic loading \\
\hline $\begin{array}{l}\text { 1. Human } \\
\text { resources }\end{array}$ & $\begin{array}{l}\text { 1. Labor productivity } \\
\text { 2. Labor profitability }\end{array}$ & $\begin{array}{l}\text { Lp1 } 1=\mathrm{LP}: \text { ASOW } \\
\mathrm{Lp} 2=\text { S prof: } \mathrm{ANW}\end{array}$ & $\begin{array}{l}\text { Characterizes a ratio of labor productivity and the } \\
\text { average salary. } \\
\text { Characterizes a sales profit, falling on one average } \\
\text { working. }\end{array}$ \\
\hline $\begin{array}{l}\text { 2. Objects of } \\
\text { the labor }\end{array}$ & $\begin{array}{l}\text { 1. Material productivity } \\
\text { 2. Material profitability }\end{array}$ & $\begin{array}{l}\mathrm{Mp} 1=\mathrm{CT}: \mathrm{MC} \\
\mathrm{Mp} 2=\mathrm{S} \text { prof: } \mathrm{MC}\end{array}$ & $\begin{array}{l}\text { Characterizes the size of the revenue received from } \\
\text { each ruble of investments in objects of the labor. } \\
\text { Characterizes the size of a sales profit from each } \\
\text { ruble of investments in objects of the labor. }\end{array}$ \\
\hline $\begin{array}{l}\text { 3. Means of } \\
\text { labour }\end{array}$ & $\begin{array}{l}\text { 1. Capital productivity } \\
\text { 2. Capital profitability }\end{array}$ & $\begin{array}{l}\mathrm{Cp} 1=\mathrm{CT}: \mathrm{AAC} \\
\mathrm{Cp} 2=\mathrm{S} \text { prof: } \mathrm{AAC}\end{array}$ & $\begin{array}{l}\text { Characterizes the size of the revenue received from } \\
\text { each ruble of investments in means of labor. } \\
\text { Characterizes the size of a sales profit from each } \\
\text { ruble of investments in means of labor. }\end{array}$ \\
\hline $\begin{array}{l}\text { 4. Financial } \\
\text { resources }\end{array}$ & $\begin{array}{l}\text { 1. Turnover rate } \\
\text { 2. Profitability of current assets }\end{array}$ & $\begin{array}{l}\text { To }=\text { CT: } \text { ARCA } \\
\text { Pca }=\text { S prof: ARCA }\end{array}$ & $\begin{array}{l}\text { Characterizes quantity of the revolutions made by } \\
\text { current assets. } \\
\text { Characterizes the profit from sale got from each } \\
\text { ruble of investments in current assets. }\end{array}$ \\
\hline $\begin{array}{l}\text { 5. Enterprise } \\
\text { resources }\end{array}$ & $\begin{array}{l}\text { 1. Coefficient of segmentation of the branch market } \\
\text { 2. Coefficient of frequency of the repeating orders } \\
\text { (contracts) } \\
\text { 3. Growth rates of number of consumers }\end{array}$ & $\begin{array}{l}\mathrm{Cs}=\text { PSbm: TSbm } \\
\mathrm{Cf}=\text { Ro: Co } \\
\text { Gr }=\text { Ccrp: Ccbp }\end{array}$ & $\begin{array}{l}\text { Characterizes the share occupied by small business } \\
\text { entity in the branch market. } \\
\text { Characterizes constancy degree in cooperation. } \\
\text { Characterizes degree of business activity. }\end{array}$ \\
\hline $\begin{array}{l}\text { 6. Intellectual } \\
\text { resources }\end{array}$ & $\begin{array}{l}\text { 1. Coefficient of compliance of level of professional } \\
\text { education to the performed work. } \\
\text { 2. Share of costs of training, increase in their qualification } \\
\text { and additional education. }\end{array}$ & $\begin{array}{l}\mathrm{Cc}=\text { Sbpec: Sbpea } \\
\mathrm{Sc}=\text { Cot: TVerp }\end{array}$ & $\begin{array}{l}\text { Characterizes degree of compliance of level of } \\
\text { professional education to requirements of the } \\
\text { performed work. } \\
\text { Characterizes degree of financial expenses in } \\
\text { formation and development of intellectual } \\
\text { resources. }\end{array}$ \\
\hline
\end{tabular}

Symbols: LP - labour productivity (development on one working); ASOW - average salary of one working; S prof- sales profit; ANW - average number of working; CT - sales proceeds (capital turnover); $\mathrm{MC}$ - material costs; AAC - average annual cost of the fixed business assets; ARCA - average remains of current assets; PSbm - product sales in the branch market; TSbm - the total sales from sales received by the branch market; Ro - the number of the repeating orders; Co total number of the concluded orders; Ccrps - number of clients with whom contracts in the reporting period are signed; Ccbp - the number of clients with whom contracts in the basic period are signed; Sbpec - number of staff with the basic professional education corresponding to branch specifics of business;

Sbpea - number of staff with basic profile education according to the plan (calculation); Cot - costs of training, professional development; TVerp - the total value of expenses in the reporting period.

Based on the conclusions of the scientists who devoted the researches to cyclic fluctuations and the cycloforming factors, authors offer on the basis of combinations of values of indicators of use of resources, to establish (to identify) the equilibrium and oscillatory processes taking place in a system (table 4).

Table 4. Types of the economic stability (ES) of small enterprises by sign-efficiency of use of the consumed resources.

\begin{tabular}{lll}
\hline $\begin{array}{l}\text { Type of economic } \\
\text { stability }\end{array}$ & $\begin{array}{l}\text { Combination of values of } \\
\text { factors of economic stability }\end{array}$ & Justification \\
\hline $\begin{array}{l}\text { Absolute economic } \\
\text { stability }\end{array}$ & $\begin{array}{l}1,36<\mathrm{TIIR}< \\
1,61<\mathrm{IIR}<\end{array}$ & $\begin{array}{l}\text { Ideal, theoretically possible economic state for the Russian small business } \\
\text { High economic }\end{array}$ \\
$\begin{array}{l}\text { Financing is carried out at the expense of normal sources, attraction of the loan capital provides } \\
\text { stability }\end{array}$ & $1,51<\mathrm{TIIR}<1,35$ & $\begin{array}{l}\text { economic benefits, investments into fixed capital become covered by long-term sources of } \\
\text { financing, information on market balance allows to balance resources which degree of }\end{array}$ \\
\hline
\end{tabular}




\begin{tabular}{|c|c|c|}
\hline $\begin{array}{l}\text { Type of economic } \\
\text { stability }\end{array}$ & $\begin{array}{l}\text { Combination of values of } \\
\text { factors of economic stability }\end{array}$ & Justification \\
\hline & & $\begin{array}{l}\text { efficiency of use high, at the same time rates of gain of a resource productivity are in a limit } \\
\text { from } 21 \% \text { to } 35 \%\end{array}$ \\
\hline $\begin{array}{l}\text { Normal economic } \\
\text { stability }\end{array}$ & $\begin{array}{l}1,01<\mathrm{TIIR}<1,20 \\
1,2<\mathrm{IIR}<1,5\end{array}$ & $\begin{array}{l}\text { Financing is carried out at the expense of normal sources, but attraction of the loan capital does } \\
\text { not provide economic benefits, investments into fixed capital become covered by long-term } \\
\text { sources of financing, information on market balance allows to balance resources which rates of } \\
\text { gain of efficiency of use are in a limit from } 1 \% \text { to } 21 \%\end{array}$ \\
\hline $\begin{array}{l}\text { Unstable economic } \\
\text { situation }\end{array}$ & $\mathrm{TIIR}=1,00 ; \mathrm{IIR}=1,00$ & $\begin{array}{l}\text { Financing of the current activity is carried out at the expense of normal sources, but degree of } \\
\text { dependence on external sources of financing which attraction does not provide economic } \\
\text { benefits accrues. Investments into fixed capital become covered by long-term sources of } \\
\text { financing, there is not enough information on market condition, the steady condition of } \\
\text { efficiency of use of the consumed resources is observed. }\end{array}$ \\
\hline $\begin{array}{l}\text { Pre-crisis economic } \\
\text { situation }\end{array}$ & $\mathrm{TIR}<1,00 ; \mathrm{IIR}=1,00$ & $\begin{array}{l}\text { Insufficiency of information on market condition does not allow to form the range of the sold } \\
\text { products, the enterprise incurs the raised expenses, works at a loss, loan of means considerable } \\
\text { and does not provide economic benefits, equity is absent or has dynamics to decrease, decrease } \\
\text { in efficiency of use of the consumed resources is observed. }\end{array}$ \\
\hline $\begin{array}{l}\text { Crisis economic } \\
\text { situation }\end{array}$ & $\mathrm{IIR}<1,00 ;$ TIIR $<\mathrm{I}, 00$ & $\begin{array}{l}\text { Financial and economic activity is financed completely by the loan and attracted capital, } \\
\text { insufficient information about market condition does not allow to provide balance of resources } \\
\text { and to create the production program, decrease in rates and indicators of efficiency of use of the } \\
\text { consumed resources is observed. }\end{array}$ \\
\hline
\end{tabular}

Symbols:

IIR - index of use of resource potential;

TIIR - growth rates of the index of use of resource potential.

\section{Instrumental and Methodological Apparatus of Strategic Audit in Small Business Based on the Concept of Resource-Based Approach}

Control of efficiency of use of resources, development and managements of a system provides strategic audit which adaptation in small business in a format of the resource focused approach is presented in table 5 .

Table 5. Contents of procedures of strategic audit of development of small enterprises in a format of the concept of the resource focused approach.

\begin{tabular}{|c|c|}
\hline Strategy purpose & Contents of procedures of strategic audit \\
\hline $\begin{array}{l}\text { Development of economic } \\
\text { potential }\end{array}$ & $\begin{array}{l}\text { 1. The analysis of resource providing and its compliance to the stated purposes } \\
\text { 2. Assessment of a state and dynamics of development } \\
\text { 3. Assessment of economic potential and the qualitative and quantitative analysis of its forming factors } \\
\text { 4. Audit of the key financial and economic indicators } \\
\text { 5. Conclusions, justification of recommendations concerning the development strategy }\end{array}$ \\
\hline $\begin{array}{l}\text { Development of financial } \\
\text { potential }\end{array}$ & $\begin{array}{l}\text { 1. The analysis of financial security and its compliance to the stated purposes } \\
\text { 2. Assessment of a state and dynamics of development } \\
\text { 3. Assessment of financial potential and the qualitative and quantitative analysis of its forming factors } \\
\text { 4. Audit of the key financial and economic indicators } \\
\text { 5. Conclusions, justification of recommendations concerning the development strategy }\end{array}$ \\
\hline $\begin{array}{l}\text { Increase in financial stability } \\
\text { and independence }\end{array}$ & $\begin{array}{l}\text { 1. Analysis of providing with economic and financial resources, their compliance to the purposes and problems of the } \\
\text { movement of a system, assessment of a state and use } \\
\text { 2. Assessment of a state and dynamics of development of a system, degree of its financial stability and independence } \\
\text { 3. Audit of all financial and economic indicators } \\
\text { 4. Conclusions, justification of recommendations concerning the development strategy }\end{array}$ \\
\hline Improving competitiveness & $\begin{array}{l}\text { 1. Analysis of a state and dynamics of development of a system } \\
\text { 2. Complex analysis of efficiency and intensification of activity } \\
\text { 3. Audit of all indicators of accounting (financial) reports } \\
\text { 4. Analysis of prospects of continuous activity of a system and development of its potential } \\
\text { 5. The analysis of competitiveness of a system and its positioning in a business environment } \\
\text { 6. Conclusions, justification of recommendations concerning the development strategy }\end{array}$ \\
\hline $\begin{array}{l}\text { Steady growth and } \\
\text { development }\end{array}$ & $\begin{array}{l}\text { 1. Analysis of a state, potential and dynamics of development of a system } \\
\text { 2. The complex analysis of efficiency of activity with identification of extent of influence of intensive and extensive, } \\
\text { endogenous and exogenous factors } \\
\text { 3. Audit of accounting (financial) reports } \\
\text { 4. The analysis of competitiveness of a system and its positioning in a business environment } \\
\text { 5. The analysis of internal and external potential of competitiveness of a system with its differentiation on blocks: } \\
\text { economic, social, ecological } \\
\text { 6. Assessment of effective management of strategy } \\
\text { 7. Conclusions, justification of recommendations concerning alternatives of the development strategy (taking into } \\
\text { account variability of registration approaches) }\end{array}$ \\
\hline
\end{tabular}


In the Lima Declaration of the guidelines of control adopted on $1 \mathrm{X}$ the Congress of the International organization of the supreme control bodies (INTOSAI) in 1977, by Article 4 it is fixed that audit of efficiency "is directed to check of that, public funds are how effectively and economically spent. Such control includes not only specific aspects of management, but also all administrative activity, including organizational and administrative systems [6]. For audit of efficiency of development of the "small business" system in its strategic management the system of the following indicators is offered:

1. Coefficient of Cumulative Relative Economy of Resources (CCRER);

2. Coefficient of Efficiency of Use of Resources (CEUR);

3. Coefficient of Cumulative Profitability (CCP);

4. Effectiveness Ratio of Functioning of a System (ERFS).

The coefficient of cumulative relative economy of resources is offered to be determined by the following algorithm:

$$
\mathrm{CCRER}=1 /(\mathrm{RE} 1+\mathrm{RE} 2+\mathrm{RE} 3+\mathrm{RE} 4)
$$

Where: RE1-relative economy of human resources, thousand rubles;

RE2-relative economy of financial resources, thousand rubles;

RE3-relative economy of means of labor, thousand rubles;

RE4-relative economy of objects of the labor, thousand rubles.

Relative economy (overexpenditure) on human resources is offered to be counted as multiplication of a deviation of average number working for the average salary one working in the audited period. The effectiveness ratio of functioning of a system is offered to be estimated (to calculate) by a formula:

$$
\mathrm{ERFS}=\mathrm{CCRER}+\mathrm{CEUR}+\mathrm{CCP}
$$

Where: CCRER - coefficient of cumulative relative efficiency of resources; CEUR - coefficient of efficiency of use of resources; CCP- coefficient of cumulative profitability.

\section{Conclusion}

Small business - a system with effective development and management which solves strategic objectives and problems of national economy and at the same time, it has a number of distinctive features, one of which - functioning in the conditions of limited resource providing. The limitation of resource providing, the set vector of sustainable development on the basis of innovations, imperatively predetermine search of new approaches to strategic management, the analysis and audit including in a format of resource focused.

\section{References}

[1] Korosteleva E. M. The resource focused approach: analysis of critical responses//Topical issues of economic sciences. - 2017 No. 18 of Page 403-408.

[2] Order of the Government of the Russian Federation of 13.11.2009 No. 1715-P "About the energy strategy of Russia until 2030".

[3] Federal law 209-FZ of 24.07.2007. "About development of small and average business of the Russian Federation".

[4] Andreychikov, A. V. The system analysis and synthesis of strategic decisions in innovatics. Bases of strategic innovative management and marketing / A. V. Andreychikov, O. N. Andreychikova. - M.: Librok, 2017. - 248 with.

[5] Hodkinson, Gerrard Competent organization. Psychological analysis of strategic management / Gerrard Hodkinson, Paul Sperrou. - M.: Humanitarian center, 2016. - 392 with.

[6] The Lima Declaration of the guidelines of control" (It is accepted in Lima 17.10.1977 26.10.1977 by the IX Congress of the International organization of the supreme bodies of financial control (INTOSAI)).

[7] All about quality. Foreign experience. Issue 54. Kano's theory of attractive quality. ISO 14064 standards for greenhouse gases. - M.: NTK Trek, 2017. - 341 p.

[8] Gerasimova, L. N. Professional values and ethics of accountants and auditors. Textbook / L. N. Gerasimov. Moscow: Yurayt, 2016. - 320 p.

[9] Grachev, Maria Internal control and audit in the public administration of developed countries: monograph. / Maria Gracheva. - Moscow: LAP Lambert Academic Publishing, 2016. - 116 p.

[10] Zharylgasov, B. T. Russian and international standards on auditing / V. T. Zharylgasov. - Moscow: KnoRus, 2017. - 400 p.

[11] Livshits, I. A., methods of assessment and audits in integrated management systems, Ilya Livshits. - Moscow: LAP Lambert Academic Publishing, 2017. - 116 p.

[12] Losev, N. Mmm. Methodology of internal audit standards / Natalia Loseva. - Moscow: LAP Lambert Academic Publishing, 2017. - $540 \mathrm{p}$. 